\title{
Analytical Hierarchy Process Method for Finding Suitable Urban Participative Management
}

\author{
[ Achmad Syarifudin, Amirudin Syarif, Qoriani, Lin Yan Syah ]
}

\begin{abstract}
The drainage network system in an area is designed to accommodate the normal flow of water. On The other hand performances of a city drainage network system is influenced significantly by the community involving throught a called particivative management patterns. This paper aims: 1) To evauate evaluate the performance of the drainage network system in Bendung watershed; 2) To measuring and finding out the level of community understanding of the functioning of sustainable drainage systems, and the level of community awareness; 3) To formulates, and develops Policy Support System (PSS) based on a community participation as drainage network rehab. The important of research has to be done is consider to the lack of integration of watershed system and partisivative management in drainage. It is according to interrelation between existing watersheds and community. The inclusion of public participation has not been optimal. This research using descriptive evaluative method, and Likert scale to grab qualitative data. Analytical Hierarchy Process (AHP) method used to formulate Policy Support System of environmentally sustainable drainage system. The research result showed that community participation could be one of the factors that make performances of Bendung watershed drainage can improved better.
\end{abstract}

Keyword: Interrelation, suitable drainage networks, policey support system, particivative management

\section{Introduction}

The flood disaster became a regular phenomenon in the rainy season which is spread in different basin in most parts of Indonesia. Total incidence of flooding in the rainy season over the last 3 years as well as the increasing number of human casualties and loss of property and facilities from public/social, transport infrastructure and infrastructure for agriculture / irrigation. In addition to the problem of precipitation as factors, the incidence of disasters can not be separated from environmental damages to ecosystems that occur in the basin and poor management of water resources.

Their land damage leading to increased surface runoff coefficient greater. The area upstream basin is an area of a particle will be increasingly vulnerable to drought, precisely the opposite downstream areas prone to flooding. Flooding is a flow that caused economic losses or even cause loss of life.

Flow can occur because of the outburst in the area in the right or left of the river due to river channel does not have enough capacity for the flow rates through.
Flooding is not only experienced by urban area located in the lowlands, even experienced area located in the highlands. Flooding or inundation in a region occurs when the system that serves to accommodate the inundation was not able to accommodate the discharge flow, it is the result of threes possibilities occur: the capacity of the system to decrease the flow rate of water increases, or a combination of both. Understanding the system here is a system of drainage network in a region.

While the drainage system can be generally defined as a series of waterworks that serve to reduce and / or remove excess water (flooding) of a region or land, so the land can function optimally, so the drainage system is an engineering infrastructure of the region to cope with the inundation floods.

Drainage network system in a region already properly designed to accommodate for normal flow rates, especially during the rainy season. This means that the capacity of the drainage channel is already taken into account to accommodate the flow of water occurs so that the area is not experiencing inundation or flooding. If the capacity of a drainage channel system decreases due to various reasons, the normal discharge even can not be accommodated by the existing system. While declining because drainage capacity, among others, there are many deposition, physical damage tissue system, the other buildings on top of the network system.

At certain times during the rainy season is often an increase in the flow rate, or there has been increased discharge caused by various reasons, the capacity of the existing system can no longer accommodate the flow rates, resulting in flooding in a region. While the cause of the increased discharge include high rainfall out of habit, changes in land use, environmental damage to the basin in a region. Then if an urban or regional decrease system capacity at the same time an increase in the flow rate, the flooding is increasing, both the frequency, extent, depth and duration.

This means that the capacity of the drainage channel is already taken into account to accommodate the flow of water occurs so that the area is not experiencing inundation or flooding. If the capacity of a drainage channel system decreases due to various reasons, the normal discharge even can not be accommodated by the existing system. While declining because drainage capacity, among others, there are many deposition, physical damage tissue system, the other buildings on top of the network system. 
Proc. of the Eighth International Conference On Advances in Civil and Structural Engineering - CSE 2018 Copyright (C) Institute of Research Engineers and Doctors. All rights reserved.

ISBN: 978-1-63248-145-0 doi: 10.15224/ 978-1-63248-145-0-30

At certain times during the rainy season is often an increase in the flow rate, or there has been increased discharge caused by various reasons, the capacity of the existing system can no longer accommodate the flow rates, resulting in flooding in a region. While the cause of the increasing discharge including high rainfall out of habit, changes in land use, environmental damage to the basin in a region.

\section{Methods}

\section{A. Location Research}

The location research is Sekanak sub-basin. The research location as in figure 3.1. (Figure 1. Map of the location study).

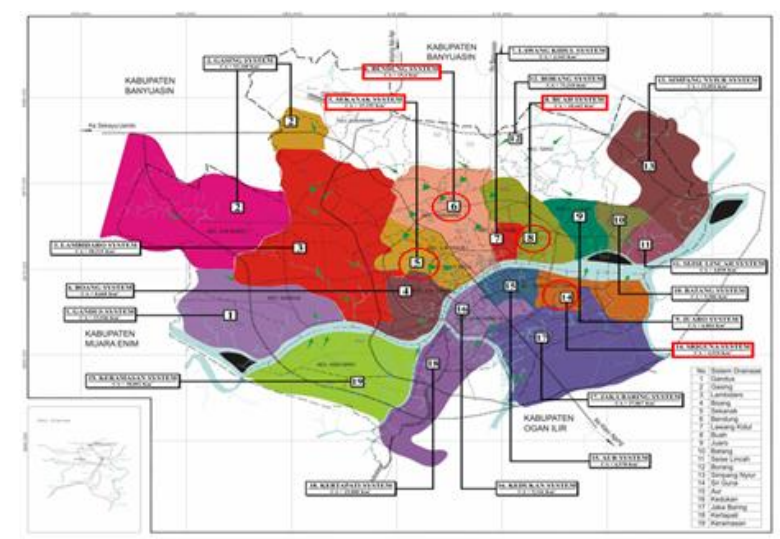

Fig.1. Research location

\section{B. Tools and Materials Research}

The tools will be used in this study are shown in Table 1.

Table 1 list of the tools used in the study

\begin{tabular}{|c|c|c|c|}
\hline No. & Name tools & Number of uses & Description \\
\hline 1 & Stationery & 1 box & Data recording \\
\hline 2 & $\begin{array}{l}\text { Computer } \\
\text { (RAM } 2 \text { GB) }\end{array}$ & 1 unit & General perform model \\
\hline 3 & Printer & 1 unit & Display report form \\
\hline 4 & $\begin{array}{l}\text { Software GIS, } \\
\text { Arc-View, } \\
\text { MS-Excel }\end{array}$ & 1 piece & $\begin{array}{l}\text { To perform modelling } \\
\text { and data processing }\end{array}$ \\
\hline 5 & $\begin{array}{l}\text { Laptop and } \\
\text { Printer }\end{array}$ & 1 unit & $\begin{array}{l}\text { Assist in preparing } \\
\text { report }\end{array}$ \\
\hline
\end{tabular}

Source: author's propose, 2016

\section{RESULTS AND DISCUSSION}

\section{A. Sekanak Watershed}

Determination of flood discharge plan to do with Synthetic Unit Hydrograph method (Synthetic unit hydrograph) Nakayasu. Before entering in the calculation of the discharge plan using Synthetic Unit Hydrograph Method Nakayasu data are necessary length of the Sekanak river and Sekanak sub-basin area. Sekanak sub-basin is divided into sub-sub-basins with the help of Global Mapper program. Sekanak subbasin can be seen in figure 2 .

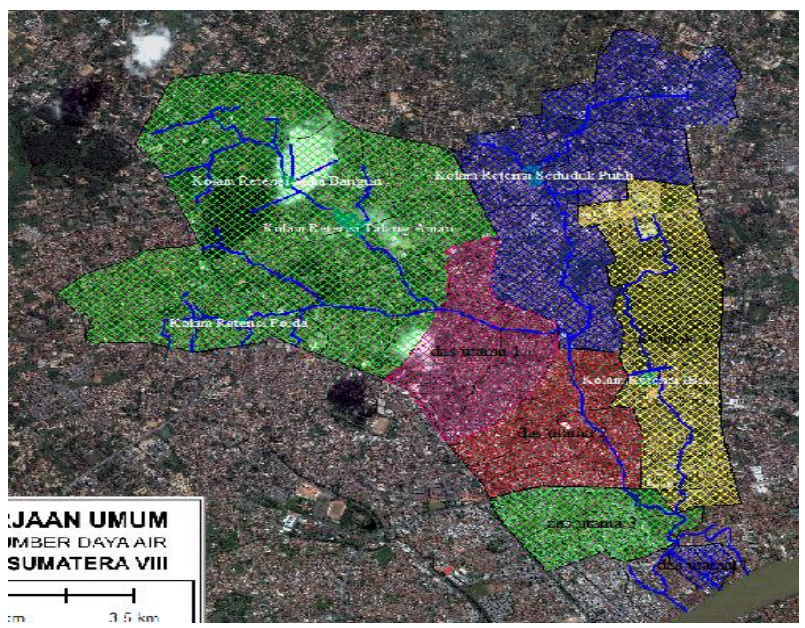

Fig. 2. Distribution of Sekanak sub-basin with Global Mapper program

\section{B. Rainfall}

Rainfall data used for 23 years, from 1991 through 2013. The data attached to the rainfall data hourly. Rainfall data can be seen in Table 2.

Table 2. Short-term data maximum rainfall

\begin{tabular}{rrrc}
\hline Years & $\begin{array}{r}\text { Duration } \\
\text { 60 minute }\end{array}$ & \multicolumn{1}{c}{ Years } & $\begin{array}{c}\text { Duration } \\
\text { 60 minute }\end{array}$ \\
\hline 1991 & 73.50 & 2003 & 71.50 \\
1992 & 80.10 & 2004 & 80.00 \\
1993 & 55.70 & 2005 & 91.90 \\
1994 & 48.50 & 2006 & 60.90 \\
1995 & 60.00 & 2007 & 65.00 \\
1996 & 47.20 & 2008 & 86.00 \\
1997 & 91.80 & 2009 & 79.50 \\
1998 & 52.30 & 2010 & 90.00 \\
1999 & 73.50 & 2011 & 80.00 \\
2000 & 70.40 & 2012 & 86.93 \\
2001 & 77.00 & 2013 & 77.63 \\
2002 & 60.90 & & \\
\hline
\end{tabular}

Source: BMKG Kenten, 2014 
Proc. of the Eighth International Conference On Advances in Civil and Structural Engineering - CSE 2018 Copyright (C) Institute of Research Engineers and Doctors. All rights reserved.

ISBN: 978-1-63248-145-0 doi: 10.15224/ 978-1-63248-145-0-30

Table 3 Rainfall intencity

\begin{tabular}{cccc}
\hline Years & $\begin{array}{c}\text { Intencity } \\
(\mathbf{m m} / \mathbf{h o u} \\
\mathbf{r s})\end{array}$ & Years & $\begin{array}{c}\text { Intencity } \\
(\mathbf{m m} / \mathbf{h o u r} \\
\mathbf{s})\end{array}$ \\
\hline 1991 & 73.50 & 2003 & 71.50 \\
1992 & 80.10 & 2004 & 80.00 \\
1993 & 55.70 & 2005 & 91.90 \\
1994 & 48.50 & 2006 & 60.90 \\
1995 & 60.00 & 2007 & 65.00 \\
1996 & 47.20 & 2008 & 86.00 \\
1997 & 91.80 & 2009 & 79.50 \\
1998 & 52.30 & 2010 & 90.00 \\
1999 & 73.50 & 2011 & 80.00 \\
2000 & 70.40 & 2012 & 86.93 \\
2001 & 77.00 & 2013 & 77.63 \\
2002 & 60.90 & & \\
\hline
\end{tabular}

Source: BMKG Kenten, 2014

\section{Frequency Analysis}

Before analyzing rainfall distribution, first determine the parameters of existing statistics. Then calculate the total amount, the amount of data (n), the maximum data $\mathrm{Ri}$ average, standard deviation (S), Coeffisien of Variation (Cv), Coeffisien of Skewness (Cs), and Coeffisien of kurtosis (Ck).

The result of the calculation as follows:
a. Total amount $=1660.26 \mathrm{~mm} /$ hour
b. Total rainfall data, $\mathrm{n}=23$
c. On average $\mathrm{Ri}=72.18 \mathrm{~mm} / \mathrm{h}$
d. The standard deviation $(\mathrm{S})=13.66$
e. Coeffisien of Variation $(\mathrm{Cv})=0.19$
f. Coeffisien of Skewness $(\mathrm{Cs})=-0.34$
g. Coeffisien of kurtosis $(\mathrm{Ck})=-0.90$

\section{Rainfall Intensity}

The intensity of rainfall that is used is the rainfall intensity data from the calculation of the Normal Distribution.

Table 4 Rainfall intencity

\begin{tabular}{cc}
\hline $\mathbf{R}($ Year $)$ & $\begin{array}{c}\mathbf{X}_{\mathbf{T}} \\
(\mathbf{m m} / \mathbf{h o u r s})\end{array}$ \\
\hline 2 & 72.18 \\
5 & 83.66 \\
10 & 89.67 \\
20 & 94.59 \\
50 & 100.19 \\
100 & 104.01 \\
\hline
\end{tabular}

Source: analysis result, 2016
Period re-elected for further calculations that the return period of 2 years.

\section{E. Run-off Coefficient}

Run-off coefficient reflects the state of the surface flow area. Drainage coefficient, $\mathrm{C}$ is the ratio of the volume of water that reached the mouth of the river basin with the volume of water that fell on the watershed. Value for drainage coefficient, $\mathrm{C}$ can be seen in Table 5.

Data obtained from Bappeda Kota Palembang, extensive land use for residential areas are:

Size high density $=7.09 \mathrm{~km}^{2}$

Extensive catchment area $=7.37 \mathrm{~km}^{2}$

Comprehensive trade area $=4.73 \mathrm{~km}^{2}$

Based on the flow coefficient table 5 for residential areas with a high density area and retrieved 0.70 to 0.20 wide catchment areas taken as well as to extensive trade area taken 0.90 .

Then the value $\mathrm{Cw}$ : runoff coefficient values obtained, $\mathrm{Cw}=0: 56$ and in the calculation taken $\mathrm{Cw}=$ 0.60 .

Table 5 Run-off Coefficient

\begin{tabular}{clc}
\hline Region & \multicolumn{1}{c}{ Land use } & C \\
\hline Urban & Rural Settlement Region: & \\
& - Low density & $0,25-0,40$ \\
& - Middle density & $0,40-0,70$ \\
& - High density & $0,70-0,80$ \\
& - With wells impregnation & $0,20-0,30$ \\
& Trade zzone & $0,90-0,95$ \\
& Industry region & $0,80-0,90$ \\
\multirow{5}{*}{ Rural } & Parks, green lanes, gardens, etc. & $0,20-0,30$ \\
& Hills, slopes < 20 percent & $0,40-0,60$ \\
& Canyons region, the slope of $>20$ & $0,50-0,60$ \\
& percent & $0,25-0,35$ \\
& Land with terracing Rice fields & $0,45-0,55$ \\
\hline
\end{tabular}

Source: PUBMSDA, 2014

\section{F. Discharge Curve}

Once the entire value discharge curve for each interval time is unknown, enter these value in the table below to get the value of runoff that occurs on an hourly basis with certain variations in rainfall. Unit hydrograph of Sekanak Sub-basin can be seen figure 3 .

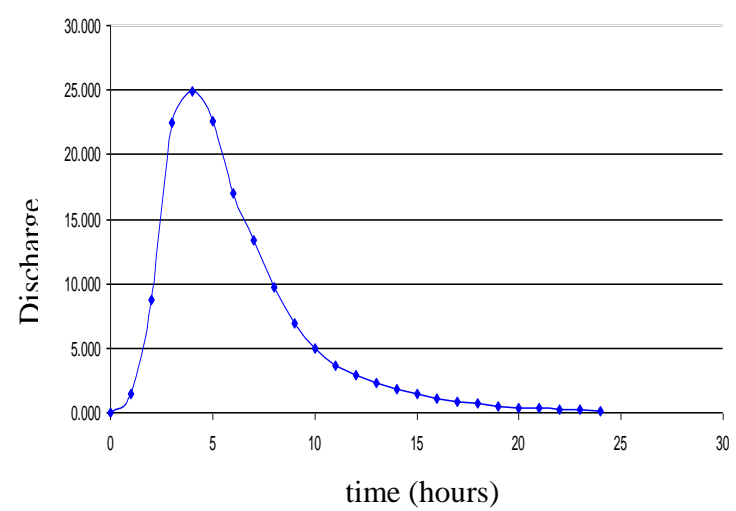

source: analysis result, 2016 
Proc. of the Eighth International Conference On Advances in Civil and Structural Engineering - CSE 2018 Copyright $(\subseteq$ Institute of Research Engineers and Doctors. All rights reserved.

ISBN: 978-1-63248-145-0 doi: 10.15224/ 978-1-63248-145-0-30

Fig 3. The unit hydrograph Synthetic of Sekanak sub-basin

\section{G. Land free of Sekanak river}

Table 6 Jalan Kapten A Rivai till the estuary of Sekanak river

\begin{tabular}{cccc}
\hline \multicolumn{4}{c}{ Amount of Strucutre } \\
\hline Picture & Left of River & Right of River & Description \\
Code & 0 & 1 & $1-2$ \\
C-3-4-02 & 4 & 4 & $2-3$ \\
C-3-2-22 & 6 & 2 & $3-4$ \\
C-3-2-25 & 1 & 6 & $4-5$ \\
C-3-2-18 & 4 & 20 & $5-6$ \\
C-3-2-14 & & 48 & \\
Total & & & \\
\hline
\end{tabular}

Note:

1-2 : Jl. Kapten A Rivai - Jl. Letnan Mukmin

2-3 : Jl. Letnan Mukmin - Jl. Letnan Jaimas

3-4 : Jl. Letnan Jaimas - Jl. SW Subekti

4-5 : Jl. SW Subekti - Lrg. Kosib II

5-6 : Lrg. Kosib II - The estuary of Sekanak River

\section{H. Condition, Land used and Structure}

For condition, land used and structure on figure 4 belows:

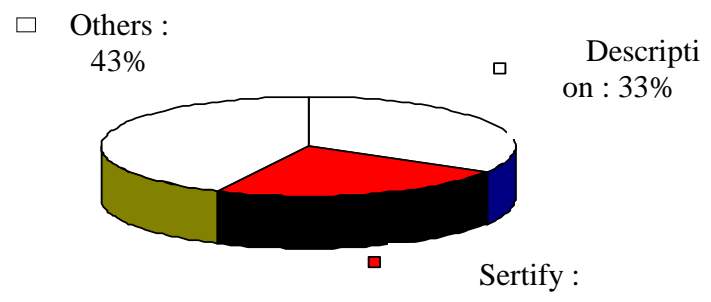

Figure 4 Land Status

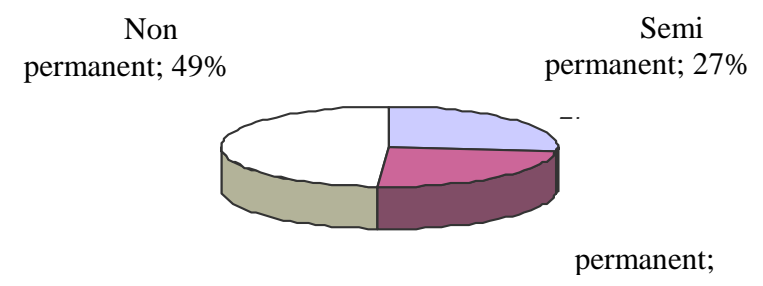

Fig 5 Structure Condition

\section{CONCLUSIONS}

Cases like mentioned above also occur in Sekanak sub-basin, so it is necessary to study the drainage network performance evaluation system based on the concept of sustainable drainage based on community participation. Drainage system performance can be evaluated from the technical aspects as well as non- technical. One technical aspect is the frequency analysis to look at the picture unit hydrograph. Analytical results from this study may be that the maximum flow of $25 \mathrm{~m}^{3} / \mathrm{sec}$ at peak hours at the time of 4.8 hours and then slowly starting to go down at a time to 24 hours.

Condition of land used and structure, only $24 \%$ structure has sertify and only $24 \%$ is permanent structure. This is problem for city government to resolve flooding area, so we need the exact data especially rainfall data.

Social construction problems can be solved by Public Participation approach, with the Government acting on the principle of fair, development activities carried out with transparency and attention to the needs of the community. Social problems occurring both at the pre-construction stage (land acquisition and resettlement), construction (procurement and mobilization of labor, mobilization of heavy equipment and construction materials and equipment operations) and post-construction can be anticipated by social engineering forming between Other identification of community character and institutions, socialization, public consultation, community gathering and community empowerment.

\section{REFERENCES}

Andrysiak, Peter B and Maidment, David, 2000, floodplain Visual Modeling with Geographic Information Systems (GIS), the Center for Research in Water Resources, Bureau of Engineering Research, The University of Texas at Austin, USA.

Chay Asdak 2004, "Hydrology and Watershed Management Area", Gadjah Mada University Press, Yogyakarta

De Groot, R. S. W, Mathew A .: Boumans, Roelf M. J, 2002, "A typology for the classificatio, description and valuation of ecosystem functions, goods and services" Ecological Economics

Hastad and Dustan 2003, Stormwater Conveyance Modeling and Design, 37 Brookside $\mathrm{Rd}$, Waterbury, USA.

Hussein, R., 2006, The Draft Basic Geographic Information System (Geographic Information System)

Jessica Pineda Z. 2005, "Maintenance of river ecosystems within urban areas", thesis, International Institute for Geoinformation Science and Earth Observaion Enschede, Urban Planning and Land A dministration, Netherlands.

Lant, C. L. K., Steven E; Beaulieu, Jeffry; Bennet, David; Loftus, imohy; Nickow, John, 2004. "Using GIS-based ecological-economic modeling to Evaluate policies affect in agricultural watersheds." Ecological Economics

C Leo Van Rijn. Principles of Fluid Flow and Surface Waves in River, Estuaries, Seas and Ocean, Aqua Publications Nederlands 1990.

M. Cahyono, 2001 Biogeographic hydraulic and water quality of rivers, ITB Bandung 
Proc. of the Eighth International Conference On Advances in Civil and Structural Engineering - CSE 2018

Copyright (C) Institute of Research Engineers and Doctors. All rights reserved.

ISBN: 978-1-63248-145-0 doi: 10.15224/ 978-1-63248-145-0-30

Marfai, Muh. Aris, 2003, GIS Modeling of River and Tidal Flood Hazards in a Waterfront City, M. Sc Thesis, ITC Enschede, The Netherlands.

Robert. J. Kodoatie, Sugiyanto, 2002, "Flood causes and methods of control in an environmental perspective.", Yogyakarta

Reini Silvia. I. Study Of Sediment Transport At Musi River In Front Of Fort Kuto Besak Palembang, Proceedings HEDS-SST, HEDS Forum, Jakarta 2006

Syarifudin, A, 2016, The influence of Musi river sedimentation to the aquatic environment, MATEC Web of Conferences journal

Syarifudin, A, and Syarif, A, 2016, Hydrograph performance of Bendung Watersheed in Palembang City, Proceeding International Conference FIRST

Syarifudin, A, SI, Momon, S.M, Arie and Suryadi, FX, 2017, Stable Channel of Reclaimed Tidal Lowland, AIP Conference Proceeding

Syarifudin, A, 2017, Environmentally Urban Drainage, Publisher Andi offset, Yogyakarta

Syarifudin, A, 2017, Applied Hydrology, Publisher Andi offset, Yogyakarta

Sagala, 2006, "Analysis of flood physical vulnerability in residential areas", disertation, the International Institute for Geoinformation Science and Earth Observaion Enschede, Netherlands

Suripin, 2004, Sustainable of Urban Drainage system, Publisher Andi, Yogyakarta 